\title{
Patterns and trends in national-level consumption and production-based utilisation of the land-system change planetary boundary
}

\author{
M. Abdullah Shaikh ${ }^{\mathrm{a},{ }^{*}, \text { Michalis Hadjikakou }^{\mathrm{a}} \text {, Brett A. Bryan }}{ }^{\mathrm{a}}$ \\ ${ }^{a}$ Centre for Integrative Ecology, School of Life \& Environmental Sciences, Deakin University, Melbourne \\ Burwood Campus, Burwood, VIC, 3125, Australia \\ *Corresponding author. E-mail address: mashai@deakin.edu.au
}

\begin{abstract}
To achieve responsible consumption and production under UN Sustainable Development Goal (SDG) 12, national agri-food consumption and production need to be assessed against environmental limits. We downscaled the Land-System Change planetary boundary and allocated national-scale environmental limits for cropland for agri-food consumption via fairshare allocation based on population, and for production via biophysical allocation based on available arable land. We assessed country-level utilisation of Land-System Change planetary boundary for cropland due to their cropland footprints. We quantified national consumption and production-based cropland footprints (including imports/exports) using an environmentally extended multi-regional input-output model and calculated the percentage utilisation of national environmental limits for cropland. Most countries' agri-food consumption footprints exceeded their fair-share cropland limit, but production utilisation of biophysical limits was less pronounced. For example, China and India were within their safe limit of consumption-based environmental limit for cropland with utilisation ratio of $80 \%$ and $74 \%$ respectively, but their utilisation ratio for production-based environmental limit was $132 \%$ and $165 \%$ respectively. Assessing country-level utilisation of the environmental limit for cropland can provide a basis for countries to act as individual entities, or together in groups, to develop policies that mitigate their global cropland impacts and minimise the risks associated with the exceedance of the Land-System Change planetary boundary.
\end{abstract}

Keywords: Planetary boundaries, downscaling, multi-regional input-output (MRIO), cropland footprint, land-system change, environmental limits.

\section{Introduction}

Large-scale conversion of land for agri-food production is adversely affecting land systems and consequently stressing the Earth's sustainable environmental limits (Godfray et al., 2010; Gopalakrishnan et al., 2011; Newbold et al., 2016; Ramankutty et al., 2018; Schneider et al., 2011; Zhao et al., 2014). The planetary boundaries framework (Rockström et al., 2009; Steffen et al., 2015) identifies critical environmental limits for nine Earth-system processes which 
delineate the safe operating space for humanity at a global level. Exceeding planetary boundaries could destabilize the Earth system and increase the likelihood of irreversible and catastrophic consequences (Steffen et al., 2018). Of these nine globally defined boundaries, the Land-System Change planetary boundary focuses on bio-geophysical processes that regulate the land surface and atmosphere (Steffen et al., 2015). As a widely used indicator (i.e., control variable) of the Land-System Change planetary boundary, total cropland area (hereafter, cropland) must remain within safe environmental limits to achieve responsible consumption and production targets mandated under the United Nations Sustainable Development Goal (SDG) 12 (UN, 2015). To support UN member countries in achieving this goal, national-level information is required on the impact of consumption-based and production-based cropland footprints on environmental limits for Land-System Change planetary boundary.

Consumption-based and production-based footprint perspectives are widely used to analyse the environmental pressures of the food system (Peters, 2008). Global displacement of land embodied in trade connects cropland footprints of countries of agri-food production to countries of consumption. These trade-facilitated flows (i.e., imports/exports) are often referred to as direct/indirect, virtual flows, or teleconnections (Liu et al., 2015). Consumption-based cropland footprint analysis allocates agri-food impacts (across the entire life-cycle) to the country where final consumption occurs, irrespective of the country of origin (i.e., production) (Kastner et al., 2014b; Rodrigues et al., 2018; Tramberend et al., 2019). Conversely, the actual on-ground biophysical pressures on domestic cropland resources in the form of cropland intensification, deforestation, biodiversity impacts, and losses in ecosystem services are reported by analysing the production-based cropland footprint (Yu et al., 2013). Thereby, production-based cropland footprint analysis assigns agri-food impacts to the country of production, rather than where final consumption occurred (Wiedmann et al., 2011a). Analysing national utilisation of the land system change planetary boundary from both the consumptionand production-based perspectives is crucial to assess human-induced environmental pressure.

To assess the environmental pressure of national agri-food consumption and production, the global-scale Land-System Change planetary boundary for cropland must be downscaled to the national level (Conijn et al., 2018; Heck et al., 2018; Li et al., 2019; O’Neill et al., 2018; Springmann et al., 2018; Willett et al., 2019). Häyhä et al. (2016) and O'Neill et al. (2018) proposed a conceptual framework to translate the planetary boundaries by using multi-stage approaches that consider biophysical, socio-economic, and ethical dimensions. Fang et al. (2015b), Dao et al. (2018), and Nykvist et al. (2013) downscaled the planetary boundaries based on a per capita approach, and Meyer and Newman (2018) introduced a quota-based approach to study planetary boundaries and human footprints. Chaudhary and Krishna (2019) quantitatively compared the changes required in consumption-based footprints to achieve sustainable diets. These downscaling approaches have potential for the assessment of consumption-based cropland footprint.

For production-based cropland footprints, the endowment of the arable land area varies widely between countries and depends on multiple factors such as total land area, topography, soils, 
climate, population, level of technological development, and overall production efficiency (Hoff et al., 2014). Hence, the focus of production-based cropland footprint assessment should shift to whether the total land area used for agri-food production in each country exceeds its available cropland (or biophysical limit). There is a need to downscale Land-System Change boundary for cropland based on the available cropland of the country. This is essential to measure country-level pressure on domestic cropland resources due to agri-food production.

In this study, we undertook a global assessment to quantify percentage utilisation of national environmental limits for cropland due to consumption and production of agri-food products from 1995 to 2011. We calculated national consumption-based and production-based cropland footprints by incorporating direct (i.e., domestic) and indirect (i.e., international) effects of virtual flows via global trade. We downscaled the global Land-System Change planetary boundary for cropland and assigned environmental limits using two methods: fair-share allocation and biophysical allocation. We assessed national consumption-based cropland footprints against fair-share cropland limits and assessed production-based footprints against biophysical limits to present a holistic national level assessment of environmental limit perturbations of cropland use for consumption and production of agri-food products. We discuss the complex global virtual flows of cropland via agri-food trade and assess the implications of national-level pressure on the Land-System Change cropland boundary due to agri-food consumption and production.

\section{Methodology}

\subsection{Overview}

We calculated annual cropland footprints using Environmentally Extended Multi-Regional Input-Output (EE-MRIO) analysis for 44 countries and five rest of the world (RoW) regions, and assessed these against cropland environmental limits downscaled according to the fairshare and biophysical allocation methods (Figure 1). This involved quantifying the percentage utilisation of fair-share cropland limits against national agri-food consumption footprints (i.e., domestic production plus imports minus exports) and quantifying the percentage utilisation of biophysical cropland environmental limits against national agri-food production footprint. We tracked inter-country virtual cropland flows in terms of imports and exports of agri-food products to identify country-to-country (cropland) trade and cropland limit exceedance over time. 


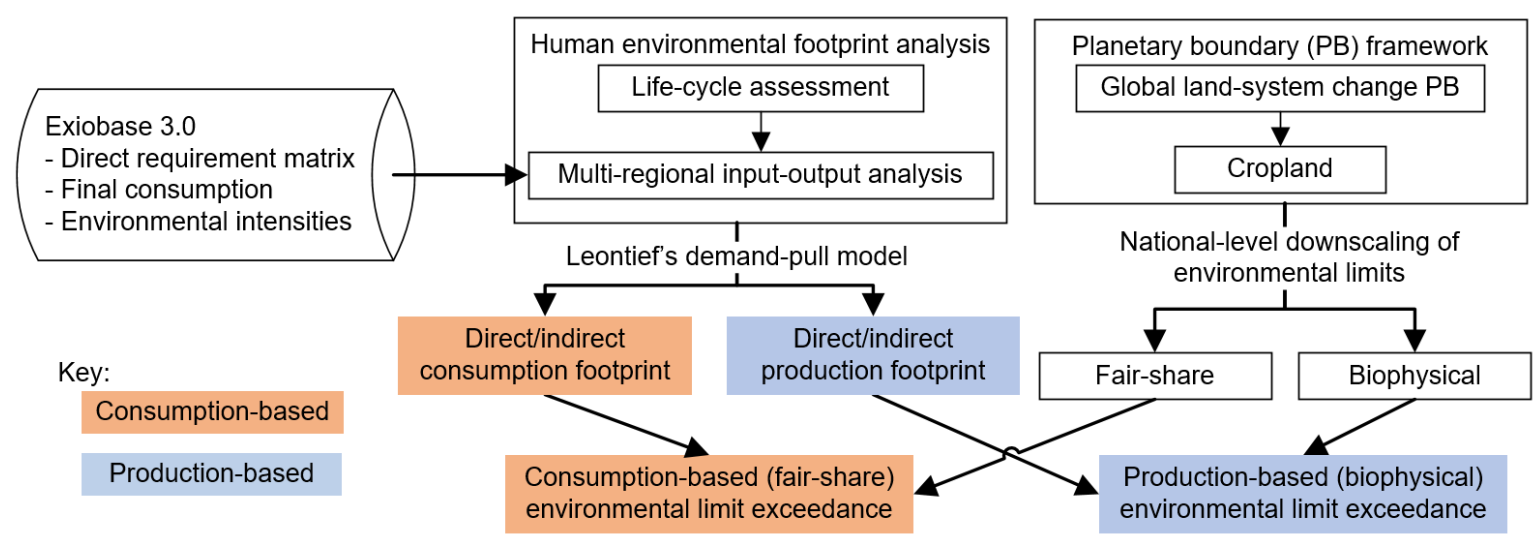

Figure 1: Schematic diagram of the methods used to link environmental footprint analysis with planetary boundaries.

\subsection{Environmental footprint analysis}

EE-MRIO modelling is the state-of-the-art method for calculating country-level, consumption and production-based footprints (Wiedmann and Lenzen, 2018). Multi-Regional Input-Output (MRIO) models use economic input-output tables for capturing global trade flows and the interdependencies between economic sectors of countries. The environmental satellite accounts in EE-MRIO databases translate trade flows into environmental units which enables the quantification of the direct/indirect environmental impacts for consumption and production (Kissinger and Rees, 2010; Weinzettel et al., 2013). We used an EE-MRIO model to calculate the direct and indirect displacement of cropland impacts embodied in global trade (Acquaye et al., 2011; Hoekstra and Wiedmann, 2014; Liu et al., 2015; Suh and Huppes, 2005; Wiedmann et al., 2011b). Global economic trade interdependencies were captured using the Exiobase 3.0 database (See Supporting Information for further details on MRIO and country aggregations), over a time series from 1995 to 2011 (Behrens et al., 2017; Wood et al., 2018). The RoW regions aggregate data from individual countries whose national input-output tables are not included in the database. A detailed explanation of the construction of the Exiobase database is provided by Stadler et al. (2018). We carried out EE-MRIO analysis to determine countries' dependencies on domestic (direct) and international (indirect) cropland resources to satisfy their domestic agri-food requirements. We used this methodology to calculate the cropland embodied in the consumption and production of agri-food products (Kastner et al., 2014a; Tramberend et al., 2019).

Our MRIO model follows the standard framework (Leontief, 1970). The technical coefficient matrix $\boldsymbol{A}$ calculated as $a_{i j}^{p q}=z_{i j}^{p q} / x_{j}^{q}$, represents the inter-sectoral monetary flow from sector $i$ in country $p$ to sector $j$ in country $q$ required to fulfil the intermediate sector demand $(z)$;

$\boldsymbol{A}=\left[\begin{array}{cccc}A^{11} & A^{12} & \cdots & A^{1 n} \\ A^{21} & A^{22} & \cdots & A^{2 n} \\ \vdots & \vdots & \ddots & \vdots \\ A^{n 1} & A^{n 2} & \cdots & A^{n n}\end{array}\right]$ 
$\boldsymbol{Y}^{\boldsymbol{p q}}$ is the matrix representing the final demand of country $q$ produced in country $p$

$\boldsymbol{Y}=\left[\begin{array}{cccc}Y^{11} & Y^{12} & \cdots & Y^{1 n} \\ Y^{21} & Y^{22} & \cdots & Y^{2 n} \\ \vdots & \vdots & \ddots & \vdots \\ Y^{n 1} & Y^{n 2} & \cdots & Y^{n n}\end{array}\right]$

The Leontief inverse matrix $\boldsymbol{L}$ is calculated by:

$L=(I-A)^{-1}$

Where $\boldsymbol{I}$ is the identity matrix, and the total output of each sector $(\boldsymbol{x})$ is calculated by:

$x=L Y$

To calculate the cropland impacts $\boldsymbol{Q}$ associated with the final demand of each country, we used the following equation:

$Q=q x=q(I-A)^{-1} Y$

Where $\boldsymbol{q}$ is the direct intensity vector representing the cropland pressures associated with the unit dollar value of economic transaction of the corresponding economic sector in each country.

\subsection{Defining the Land-System Change planetary boundary for cropland}

The environmental limits of the Land-System Change planetary boundary are widely debated (Usubiaga-Liaño et al., 2019). Rockström et al. (2009) originally proposed a Land-System Change planetary boundary as the total cropland area of no more than $15 \%$ of the global icefree land surface. Steffen et al. (2015) later revised the planetary boundary control variable from the original cropland extent to the area of forest remaining on the planet, on the premise that forests are a major driver of land-surface/climate dynamics compared to other biomes (Heck et al., 2018; West et al., 2010). However, cropland is still the most commonly reported and well-established control variable representing the Land-System Change planetary boundary in food system studies (Chaudhary and Krishna, 2019). A wide range of estimates for the cropland planetary boundary have been reported, with several refinements since originally introduced by Rockström et al. (2009). Following a review of available estimates based on recent scientific consensus (see next paragraph), we adopted a conservative boundary (in accordance with the precautionary principle) but still wide enough to encompass current uncertainty in the cropland limit.

The world's ice-free land area is estimated at $132 \mathrm{Mkm}^{2}$ (UNCCD, 2017). Based on this figure and the original 15\% cropland area planetary boundary suggestion by Rockström et al. (2009), global environmental limit for cropland equals to $19.8 \mathrm{Mkm}^{2}$. This estimate is within the range used by studies adopting the cropland boundary such as the $19.5 \mathrm{Mkm}^{2}$ estimate of Nykvist et al. (2013) and the 20.1 $\mathrm{Mkm}^{2}$ estimate of Henry et al. (2018). Even before the revision of the 
Land-System Change boundary (Steffen et al., 2015), UNEP (2014) proposed a lower estimate of $16.4 \mathrm{Mkm}^{2}$ for the cropland boundary based on the precautionary principle (Van Vuuren and Faber, 2009). Recent modelling takes into account conservation levels for each forest biome to preserve ecosystem integrity, producing an estimate of $12.6 \mathrm{Mkm}^{2}$ (with a range 10.614.6 $\mathrm{Mkm}^{2}$ ) (Springmann et al., 2018). We therefore adopted $12.6 \mathrm{Mkm}^{2}$ as the best estimate of the boundary based on the revised definition of the Land-System Change planetary boundary, but we also encompassed the earlier $16.4 \mathrm{Mkm}^{2}$ estimate by UNEP (2014) as an upper limit because, according to Springmann et al. (2018), this specific control variable could be relaxed through conversion of pasture into cropland. We adopted these low, best, and high estimates of Land-System Change planetary boundary and used them to define planetary boundary utilisation zones (Table 1).

Table 1: Planetary boundary utilisation zones of cropland limits. Utilisation ratio is the percentage utilisation of downscaled cropland environmental limit calculated as ratio of cropland footprint and the best estimate of the planetary boundary $\left(12.6 \mathrm{Mkm}^{2}\right)$.

\begin{tabular}{|c|c|c|c|c|}
\hline Zone & Colour & $\begin{array}{l}\text { Global cropland } \\
\text { limits }\left(\mathrm{Mkm}^{2}\right)\end{array}$ & $\begin{array}{l}\text { Utilisation } \\
\text { Ratio (\%) }\end{array}$ & Description \\
\hline Safe & & $<10.6$ & 0 to 83 & Below lower environmental limit \\
\hline Potentially unsafe (lower) & & 10.6 to 12.6 & 84 to 100 & Between lower and best estimate environmental limit \\
\hline Potentially unsafe (higher) & & 12.6 to 16.4 & 101 to 129 & Between best estimate and higher environmental limit \\
\hline Unsafe & & $>16.4$ & $130+$ & Above higher environmental limit \\
\hline
\end{tabular}

\subsection{Downscaling the Land-System Change planetary boundary}

We downscaled the global Land-System Change planetary boundary for cropland to the national level based on a per capita fair-share for assessment of the consumption-based cropland footprints and based on biophysical limits for assessment of production-based cropland footprints.

\subsubsection{Fair-share allocation}

A country's consumption-based cropland footprint is directly proportional to the typical diet and lifestyle of its people. Allocating a share of the global cropland planetary boundary to individual countries based on a per capita equivalent normalises the inequality in arable land endowment between countries and harmonises the comparative advantage of countries with abundant cropland over countries with limited cropland (Dao et al., 2018; Fang et al., 2015a). Thus, this downscaling technique considered that every human has an equal right to global land resources and allocated environmental limits to countries based on their proportion of the global population. To calculate the annual $(y)$ fair-share environmental limit for cropland $\left(P B^{f s}\right)$ of each country $(c)$, we multiplied the global cropland limit $\left(P B_{g}\right)$ with the national population proportion (Pop) obtained from UN (2017):

$$
P B_{c, y}^{f s}=P B_{g} * \frac{P o p_{c, y}}{P o p_{g, y}}, \text { for } c=1,2, \ldots, 49 \text { and } y=1995,1996, \ldots, 2011
$$




\subsubsection{Biophysical allocation}

The biophysical downscaling perspective allocated environmental limits to countries based on their potentially available cropland while considering the land use for forests, biodiversity, and other ecosystem services. The potentially available cropland in countries was quantified based on existing literature (Eitelberg et al., 2015; Lambin et al., 2013). The study calculated spatially defined high, medium, and low estimates of potentially available cropland using model-based approaches and considering several land-cover classes. We overlayed a national border shapefile over the raster-based Eitelberg et al. (2015) "low" estimate data of potentially available cropland using a Geographic Information System and aggregated the spatially-resolved results of each country. We considered low estimates because the medium and high potential cropland estimates included savannahs, shrublands, grasslands, forests, protected areas, and a range of other land-cover classes that are dedicated for biodiversity conservation and other ecosystem services (Eitelberg et al., 2015; Lambin et al., 2013).

Unlike the fair-share limits which vary over time with changes in population, biophysical limits are time-invariant. The biophysical environmental limit of production $P B^{\text {bio }}$ for each country $(c)$ was calculated by multiplying the global cropland limit $\left(P B_{g}\right)$ with the national proportion of the potentially available cropland $(P A C)$ :

$P B_{c}^{b i o}=P B_{g} * \frac{P A C_{c}}{\sum_{c=1}^{49} P A C_{c}}$, for $c=1,2, \ldots, 49$

\subsection{Country-level utilisation ratio calculations}

To evaluate the utilisation of national fair-share and biophysical environmental limit for consumption and production, we developed a utilisation ratio $(U R)$ indicator which was calculated by dividing the cropland footprint $(F P)$ of a country $(c)$ in year $(y)$, by the best estimate $\left(P B^{*}\right)$ of the country's cropland environmental limit for that same year.

$U R_{c, y}=\frac{F P_{c, y}}{P B_{c, y}^{*}} * 100$, for $c=1,2, \ldots, 49$ and $y=1995,1996, \ldots, 2011$

\subsection{Analysis and visualisation}

We analysed the results by plotting the consumption-based cropland footprints including direct (i.e., consumption of domestically produced agri-food products) and indirect (i.e., consumption of imported agri-food products) components against fair-share environmental limits; and production-based cropland footprints including direct and indirect (i.e., exported agri-food products) components against biophysical environmental limits. Direct and indirect cropland flows were assessed for national consumption and production footprints and visualised using chord diagrams. The full database of cropland footprints and virtual flows from 1995-2011 is presented in the Supporting Data. National-level utilisation of consumption and productionbased environmental limits were compared over time series. 


\section{Results}

\subsection{Consumption-based footprints and fair-share limits}

Fair-share cropland environmental limits have changed over time relative to the change in their individual proportion of the global population (Figure 2). China and India had the highest fairshare environmental limit for consumption due to population. These limits varied over time because of variation in population proportions. For example, China's fair-share environmental limit decreased from 2.73 to 2.46 million $\mathrm{km}^{2}$ and India's fair-share environmental limit increased from 2.10 to 2.24 million $\mathrm{km}^{2}$. Similarly, from 1995 to 2011 , the fair-share environmental limit for RoW Asia and RoW Africa increased, while it decreased for Japan, Korea, and other European countries.

In 2011, China had the highest consumption-based cropland footprints, followed by RoW Africa, India, USA, and RoW Asia. From 1995 to 2011, these footprints increased in China (from 1.27 to $1.97 \mathrm{Mkm}^{2}$ ), Turkey (from 0.30 to $0.36 \mathrm{Mkm}^{2}$ ), UK (from 0.21 to $0.23 \mathrm{Mkm}^{2}$ ), Mexico (from 0.28 to $0.34 \mathrm{Mkm}^{2}$ ), and RoW Africa (from 1.58 to $1.90 \mathrm{Mkm}^{2}$ ), but decreased in the USA (from 1.67 to $1.38 \mathrm{Mkm}^{2}$ ), Australia (from 0.27 to $0.19 \mathrm{Mkm}^{2}$ ), Russia (from 1.26 to $0.83 \mathrm{Mkm}^{2}$ ), Japan (from 0.49 to $0.39 \mathrm{Mkm}^{2}$ ), Korea (from 0.19 to $0.18 \mathrm{Mkm}^{2}$ ), Brazil (from 0.56 to $0.47 \mathrm{Mkm}^{2}$ ), and most of European countries. India, however, maintained a fairly constant cropland footprint.

Disaggregating the total consumption-based cropland footprints into direct (i.e., consumption of domestic agri-food production) and indirect (i.e., consumption of imported agri-food production) revealed cropland teleconnections associated with consumption. Major agri-food producers like India, Australia, Brazil, Mexico, United States, RoW Asia, and RoW Africa had lower indirect cropland footprints than smaller producers like Japan, South Korea, European Countries, and the UK. Many countries have become increasingly dependent on imports in order to satisfy agri-food demand. For example, indirect cropland footprints increased in Australia (from 0.03 to $0.06 \mathrm{Mkm}^{2}$ ), Brazil (from 0.07 to $0.09 \mathrm{Mkm}^{2}$ ), China (from $0.12 \mathrm{Mkm}^{2}$ in 1995 to $0.91 \mathrm{Mkm}^{2}$ in 2011), India (from 0.05 to $0.18 \mathrm{Mkm}^{2}$ ), Mexico (from 0.06 to 0.13 $\mathrm{Mkm}^{2}$ ), and the USA (0.52 to $\left.0.59 \mathrm{Mkm}^{2}\right)$. Global agri-food imports cause complex virtual cropland flows between countries (Supplementary Data). For example, in 2011, consumption of imported agri-food products caused major virtual cropland flows in Asia (others), Europe (others), China, and the USA (Figure 3, Supplementary Data). 


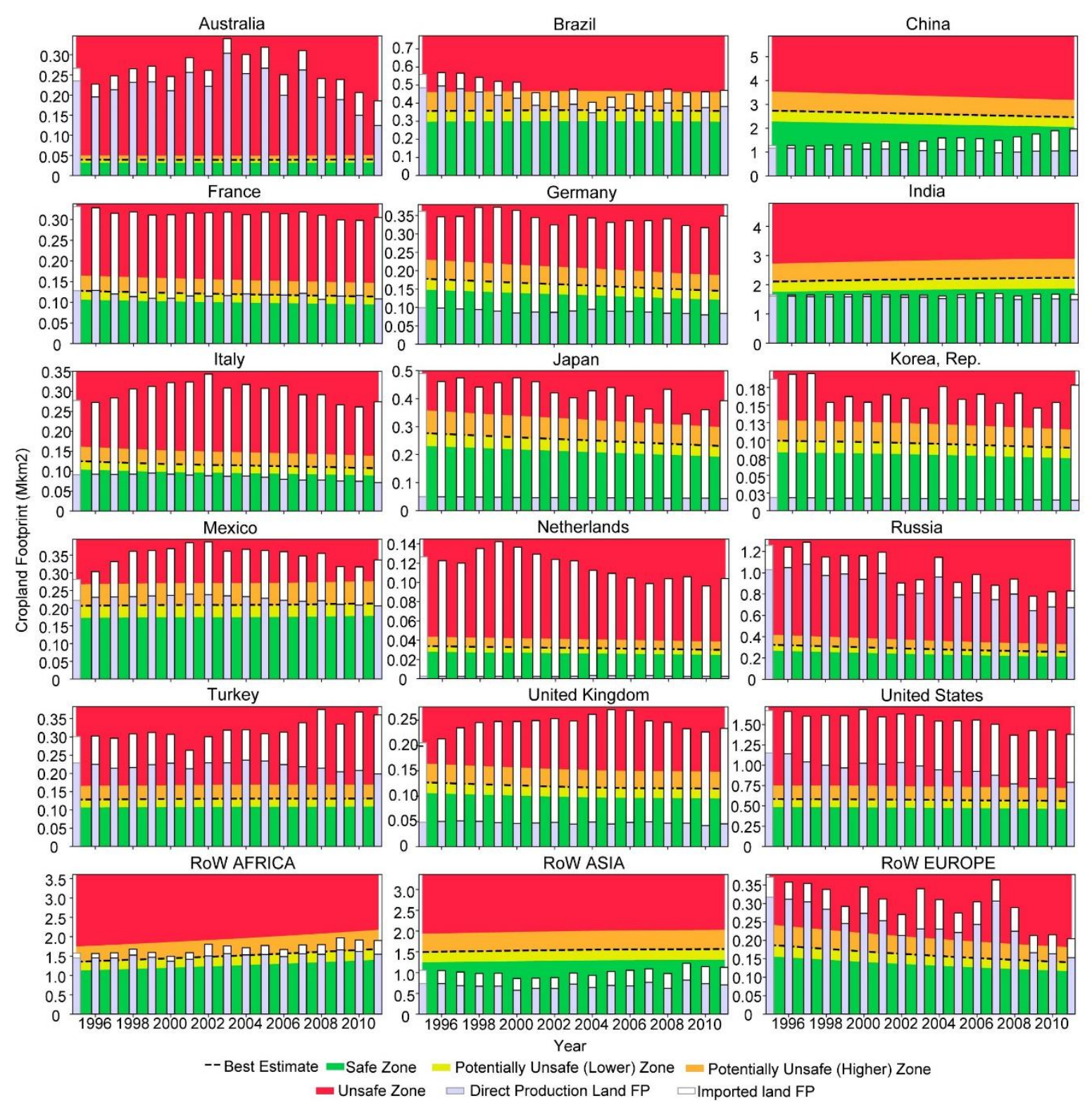

Figure 2: Comparison of selected countries' consumption-based cropland footprints against their fair-share environmental limit. Background colours show the zones of downscaled environmental limit (Table 1). Vertical bars represent the domestic (direct) and imported (indirect) cropland footprint by countries over time. Note that the scale of y-axis is unique for each country due to the difference in environmental limits and cropland footprints. See Figure A3.1 in Supporting Information (SI) for the results for all countries and world regions.

Agri-food consumption in Asia (others) was largely dependent on cropland flows from the USA (0.27 $\left.\mathrm{Mkm}^{2}\right)$, America (others) $\left(0.22 \mathrm{Mkm}^{2}\right)$, and Africa (others) $\left(0.19 \mathrm{Mkm}^{2}\right)$. Imports in Europe (others) relied on cropland flows from Asia (others) $\left(0.37 \mathrm{Mkm}^{2}\right)$ and Africa (others) $\left(0.36 \mathrm{Mkm}^{2}\right)$. Imports in China embodied cropland resources from the USA $\left(0.25 \mathrm{Mkm}^{2}\right)$ and Brazil $\left(0.17 \mathrm{Mkm}^{2}\right)$, while agri-food imports in the USA were associated with cropland flows from America (others) $\left(0.16 \mathrm{Mkm}^{2}\right)$ and Asia (others) $\left(0.12 \mathrm{Mkm}^{2}\right)$. 


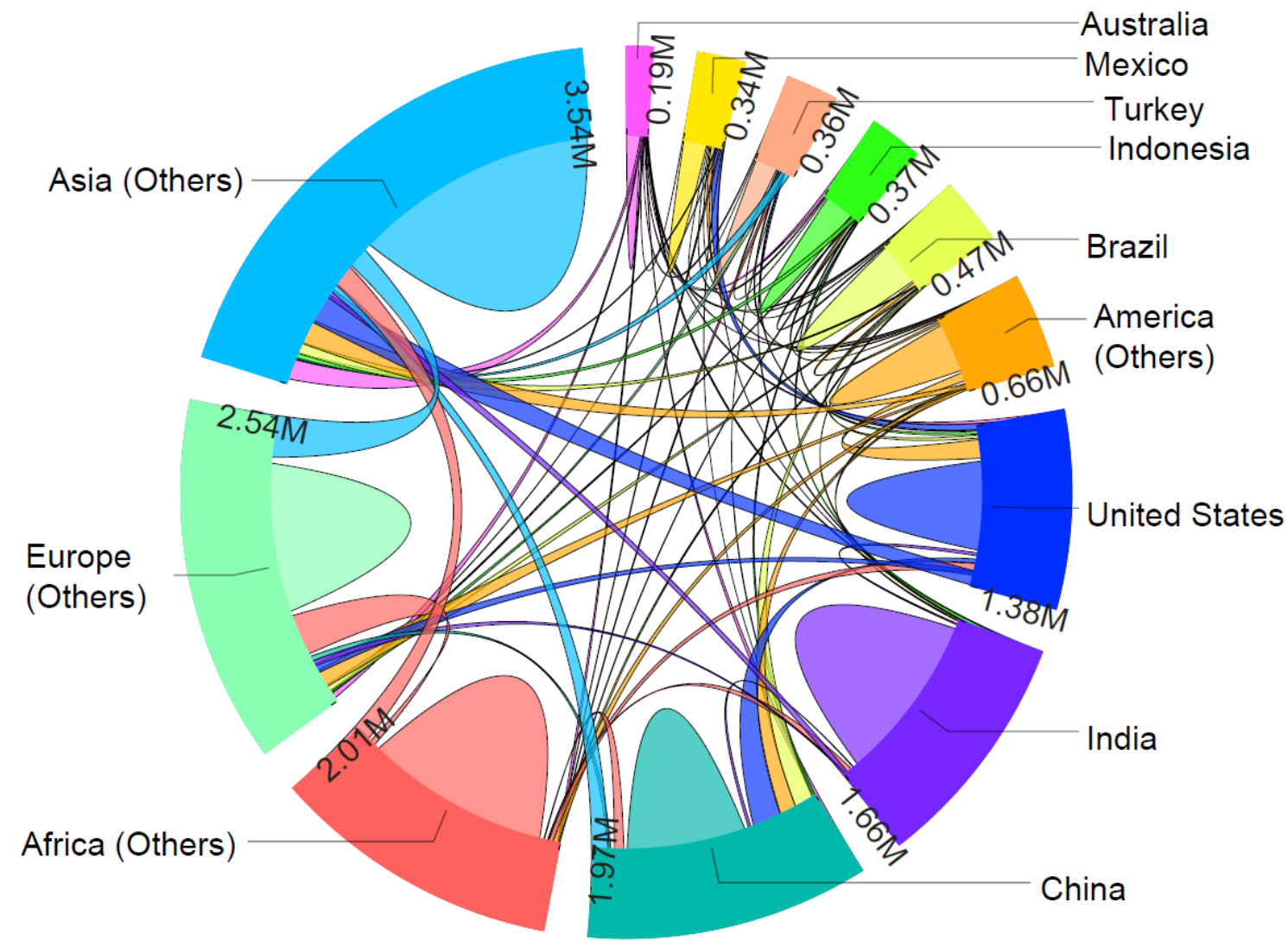

Figure 3: Consumption-based domestic (direct) and imported (indirect) cropland flows $\left(\mathrm{Mkm}^{2}\right)$. For clarity of visualisation, prominent countries are classified separately. (See Table A2.1 for country classification in Supporting Information).

\subsection{Production-based footprints and biophysical limits}

The biophysical environmental limits for RoW Africa (2.02 million $\mathrm{km}^{2}$ ), RoW Asia (1.41 million $\mathrm{km}^{2}$ ), India (1.03 million $\mathrm{km}^{2}$ ), Russia (0.96 million $\left.\mathrm{km}^{2}\right)$, China (0.95 million $\mathrm{km}^{2}$ ), and USA (0.86 million $\left.\mathrm{km}^{2}\right)$ were highest due to their large endowments of arable land (Figure 4).

In 2011, the highest production-based cropland footprints were RoW Africa (2.39 $\left.\mathrm{Mkm}^{2}\right)$, followed by India $\left(1.70 \mathrm{Mkm}^{2}\right)$, USA (1.63 $\left.\mathrm{Mkm}^{2}\right)$, RoW Asia $\left(1.50 \mathrm{Mkm}^{2}\right)$, and China $(1.25$ $\mathrm{Mkm}^{2}$ ). From 1995 to 2011, production-based footprints increased in Australia (from 0.40 to $0.48 \mathrm{Mkm}^{2}$ ), Brazil (from 0.66 to $0.79 \mathrm{Mkm}^{2}$ ), Mexico (from 0.27 to $0.28 \mathrm{Mkm}^{2}$ ), and RoW Africa (from 1.99 to $2.39 \mathrm{Mkm}^{2}$ ), but decreased in China (from 1.32 to $1.25 \mathrm{Mkm}^{2}$ ), Turkey (from 0.27 to $0.24 \mathrm{Mkm}^{2}$ ), and the USA (from 1.84 to $1.62 \mathrm{Mkm}^{2}$ ). India's production-based cropland footprint remained constant.

Exported production-based cropland footprint (i.e., indirect cropland footprint) increased for almost all countries. From 1995 to 2011, increased exports from prominent agri-food producers resulted in increased virtual cropland flows. Of the total cropland use of Australia, $0.17 \mathrm{Mkm}^{2}$ was exported to other countries in 1995, which increased to $0.36 \mathrm{Mkm}^{2}$ in 2011. Likewise, considerable increases in the indirect production-based cropland footprints were found in 
Brazil (from $0.17 \mathrm{Mkm}^{2}$ to $0.41 \mathrm{Mkm}^{2}$ ), China (from $0.16 \mathrm{Mkm}^{2}$ to $0.20 \mathrm{Mkm}^{2}$ ), India (from $0.09 \mathrm{Mkm}^{2}$ to $0.21 \mathrm{Mkm}^{2}$ ), Mexico (from $0.05 \mathrm{Mkm}^{2}$ to $0.07 \mathrm{Mkm}^{2}$ ), Russia (from $0.26 \mathrm{Mkm}^{2}$ to $0.56 \mathrm{Mkm}^{2}$ ), USA (from $0.69 \mathrm{Mkm}^{2}$ to $0.79 \mathrm{Mkm}^{2}$ ), RoW America (from $0.33 \mathrm{Mkm}^{2}$ to $0.54 \mathrm{Mkm}^{2}$ ), and ROW Africa (from $0.53 \mathrm{Mkm}^{2}$ to $0.84 \mathrm{Mkm}^{2}$ ). Global agri-food exports also cause complex virtual cropland flows. In 2011, major virtual cropland flows due to agri-food exports were from Asia (others), Africa (others), America (others), USA, Brazil, and Australia (Figure 5, Supplementary Data).

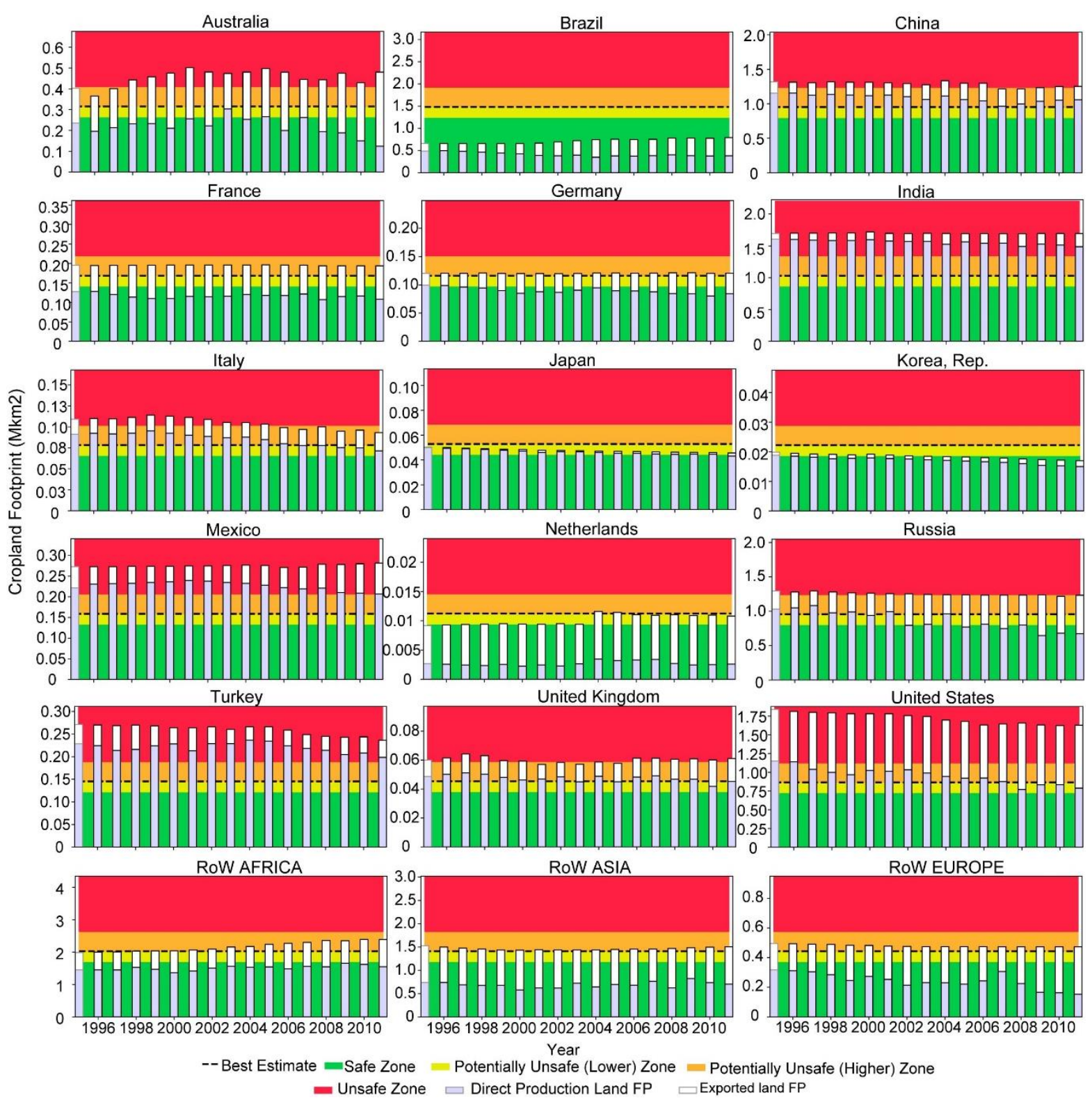

Figure 4: Comparison of selected countries' production-based cropland footprints against their biophysical environmental limit. Background colours show the zones of downscaled environmental limit (Table 1). Vertical bars represent the domestic (direct) and exported (indirect) use of cropland by countries over time. Note that the scale of y-axis is unique for each country due to the difference in environmental limits and cropland footprints. See Figure A3.2 in Supporting Information for the results for all countries and world regions. 
The largest virtual cropland flows (i.e., exports) from Asia (others) were to Europe (others) $\left(0.37 \mathrm{Mkm}^{2}\right)$, Africa (others) $\left(0.16 \mathrm{Mkm}^{2}\right)$, and China $\left(0.15 \mathrm{Mkm}^{2}\right)$. From Africa (others), cropland flows were typically to Europe (others) $\left(0.36 \mathrm{Mkm}^{2}\right)$ and Asia $\left(0.19 \mathrm{Mkm}^{2}\right)$, while from America (others) they were mostly to Asia (others) $\left(0.22 \mathrm{Mkm}^{2}\right)$ and the USA $(0.16$ $\left.\mathrm{Mkm}^{2}\right)$. From the USA, cropland flows were primarily to Asia (others) $\left(0.27 \mathrm{Mkm}^{2}\right)$ and China $\left(0.25 \mathrm{Mkm}^{2}\right)$, and from Brazil, they were mostly to China $\left(0.17 \mathrm{Mkm}^{2}\right)$ and USA $\left(0.03 \mathrm{Mkm}^{2}\right)$.

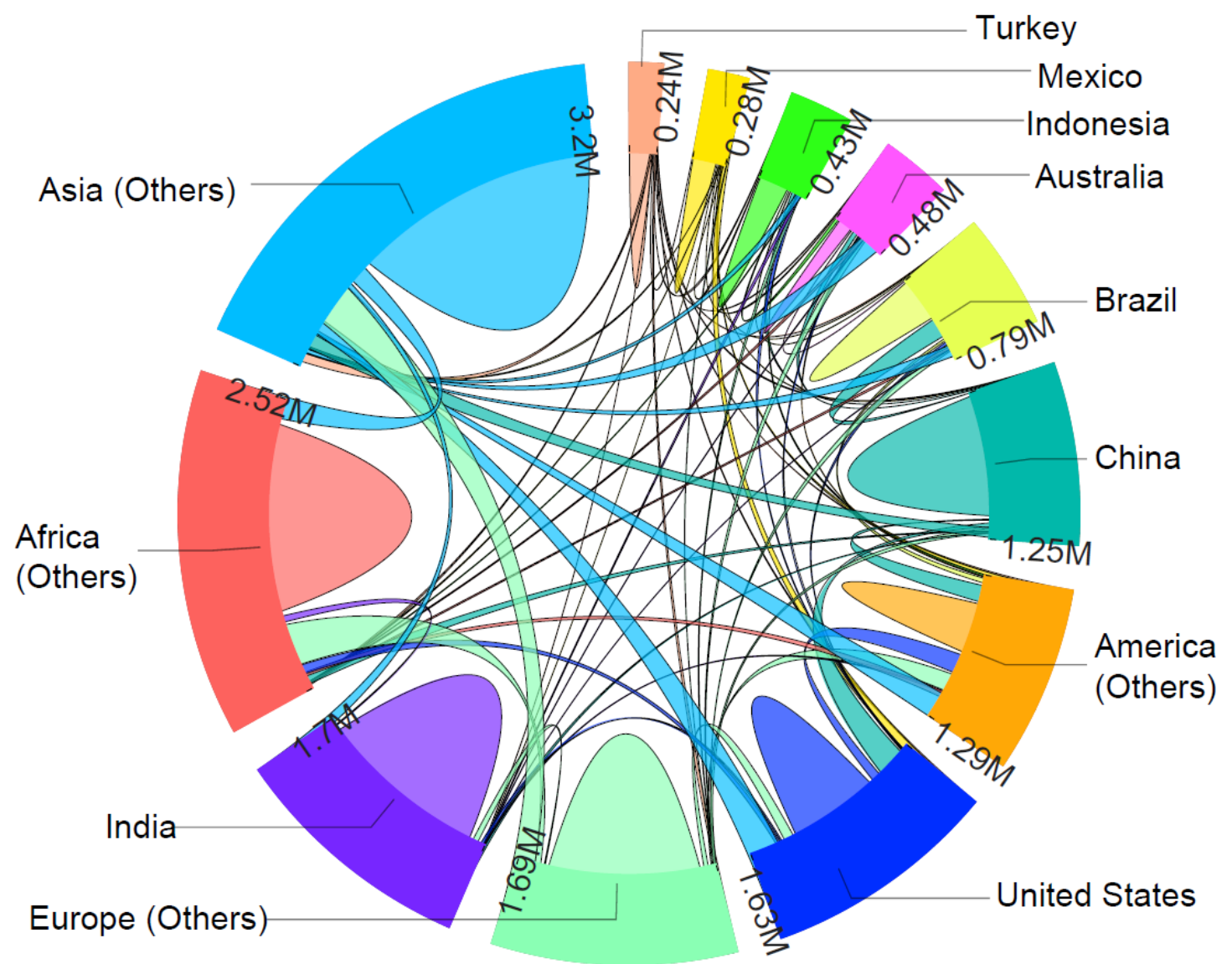

Figure 5: Production-based domestic (direct) and exported (indirect) cropland flows $\left(\mathrm{Mkm}^{2}\right)$. For clarity of visualisation, prominent countries are classified separately. (See Table A2.1 in Supporting Information for country classification).

\subsection{Consumption and production-based utilisation of environmental limits}

Cropland consumption was within fair-share environmental limits for only a few countries (as evidenced by utilisation ratios much greater than $100 \%$ in Figure 6). However, while the cropland production footprints also exceeded biophysical limits for many countries, overall utilisation ratios were lower, and several countries were safely within their biophysical cropland limits. For a few countries (e.g., China, India, RoW Asia, Indonesia), cropland consumption footprints were within their fair-share limits, but their cropland production footprints exceeded their biophysical limits. Many developed countries exceeded their environmental limits for both consumption and production. For example, Australia's cropland consumption greatly exceeded its fair-share limit $(\mathrm{UR}=461 \%)$ and its cropland production 
also exceeded its biophysical limit (UR $=152 \%)$. Similarly, the USA exceeded its fair-share environmental limit (UR $=247 \%)$ and its biophysical environmental limit (UR $=188 \%)$.

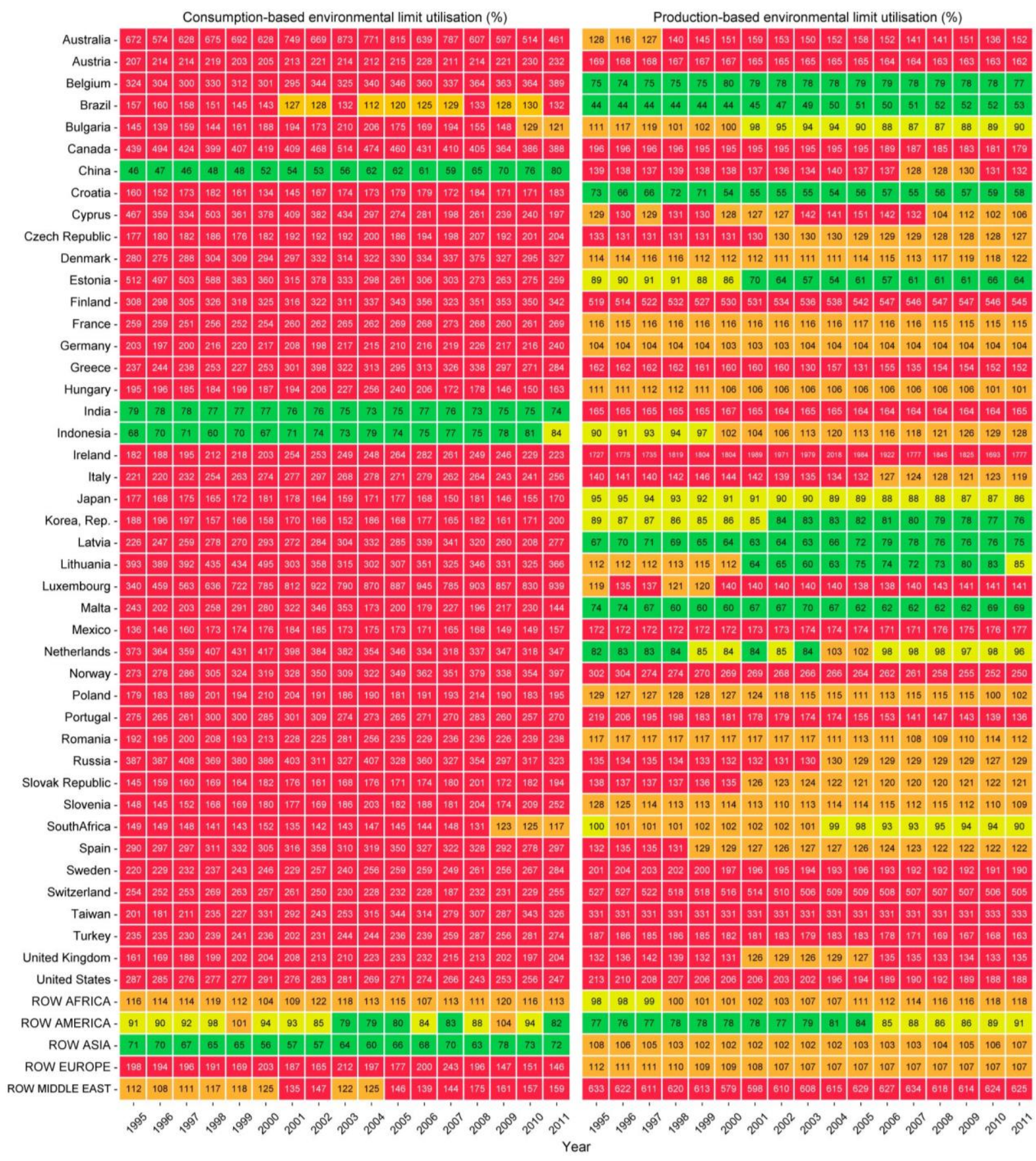

Figure 6: Percentage utilisation of countries' downscaled cropland boundary including consumption-based utilisation of fair-share limits (left) and production-based utilisation of biophysical limits (right). See Table 1 for legend. 


\section{Discussion}

We have downscaled the Land-System Change planetary boundary for cropland and allocated national cropland limits for consumption and production using fair-share and biophysical allocation, respectively. We quantified direct and indirect cropland footprints of agri-food consumption and production and assessed these footprints against the fair-share cropland limit for consumption and biophysical cropland limit for production, given the complex global virtual flows of cropland via agri-food trade. We showed how countries utilised their downscaled cropland environmental limit for consumption and production of agri-food.

\subsection{Global cropland consumption, production, flows, and boundary utilisation}

Agri-food consumption in most countries exceeded their fair-share cropland limit. China, India, Indonesia, and RoW Asia were the only countries that remained within their respective fairshare cropland limit within the study period. The large populations of these countries drove a high fair-share environmental limit, and the relatively low agri-food demand per capita resulted in a low consumption-based footprint. However, upward trends of consumption-based cropland footprints suggests that even these countries may have exceeded their fair-share limit by the time of writing (2020). Although many countries had exceeded production-based biophysical limits, utilisation ratios tended to be lower than consumption-based fair-share utilisation ratios. Brazil and RoW America were among the few countries whose agri-food production had not exceeded their biophysical cropland limit within the study period. However, deforestation and cropland intensification to meet growing domestic and export demands are increasingly putting pressure on biophysical limits in these regions (Ramankutty et al., 2018).

Difference between consumption and production-based percentage utilisation was due to the fundamental differences between the calculation of fair-share versus biophysical environmental limits and the limited correlation between the population and available arable land of nations. Consumption and production-based cropland footprint vary with countries' population, wealth, urbanisation, culture and lifestyle, and geography (Willett et al., 2019). Levels of agri-food imports and exports of countries are influenced by production efficiency, environmental impacts, socio-economic, and cultural factors (Osei-Owusu et al., 2019). These factors explain the fluctuations of consumption-based and production-based cropland footprints and associated variation in import and export of agri-food products. Trends towards increasing indirect consumption-based footprints provide evidence in support of claims that global outsourcing of agri-food products is increasing (Simas et al., 2017; Yu et al., 2013), and along with it the increasing indirect cropland impacts on biophysical cropland limit of exporting countries.

Global trade in agri-food products illustrates how complex teleconnections result in the exceedance of biophysical cropland limits of exporting countries (Green et al., 2019). For example, China exports cotton, oil seeds, sugarcane, and other products to USA, Japan, South Korea, and Asia (Yu et al., 2016). The USA exports corn, soybeans, and livestock (Sun et al., 
2019) and Australia exports wheat, fruits, vegetables, and other products to Asia and Europe. Hence, agri-food exports of most countries contribute to the utilisation of nationallydownscaled production-based biophysical environmental limits for cropland.

\subsection{Innovation and contribution}

Environmental footprint studies have typically focused on the consumption-based perspective in order to assess environmental sustainability (Cuypers et al., 2013; Davis et al., 2017; Turner et al., 2007), arguing that this perspective best captures the appropriation of natural capital, resource use, and the environmental impacts of human activities (Bruckner et al., 2015; Tramberend et al., 2019; Tukker et al., 2016). While this accounting approach is useful for evaluating the strong coupling between environmental pressures and affluence, we also analysed the production-based perspective because of its relevance in quantifying the environmental impacts of goods and services produced for human use (Croft et al., 2018). However, considering both the consumption and production-based perspectives is essential for sustainability assessment due to fundamental differences in natural resource availability, cropland suitability, and other factors that determine country-to-country trade and drive virtual cropland flows described above (Sun et al., 2019).

A major innovation of this study is in allocating biophysical cropland limits to countries to assess production-based cropland footprints. Studies that have considered the consumptionbased footprints against the national environmental limits have mainly used the fair-share (per capita) approach to assign environmental limits for consumption (Fang et al., 2015a; Fang et al., 2015b; Li et al., 2019; O’Neill et al., 2018; Springmann et al., 2018; Willett et al., 2019). The country-level resolution and time-series analysis of our study also goes well beyond the scope of previous global cropland footprint assessments (Dao et al., 2018; Fang et al., 2015b).

Assigning shares of the global safe operating space to countries and assessing their cropland footprints against these environmental limits is used to quantify national environmental pressures on shared global land resources. Currently, downscaling planetary boundaries based on population is the most common downscaling approach (Dao et al., 2018). The framework used in this study provides a novel way to allocate national environmental limit for production based on biophysical limit of countries. This methodology can be replicated for other planetary boundaries by using relevant control variables. Our study considered key nuances in the LandSystem Change planetary boundary by addressing ethical and biophysical concerns that generally arise in allocating the safe operating space to countries (Häyhä et al., 2016; Newbold et al., 2016).

\subsection{Policy implications and SDG 12 implementation}

Environmental impacts caused by agri-food production are the shared responsibility of consumers and producers (Lenzen et al., 2007). The principles of responsible consumption and production (SDG 12) require countries to monitor both their direct and indirect footprints, as well as their respective impacts on environmental limits (Tukker et al., 2016). Our results 
provide a national-level assessment of how cropland resources are utilised for consumption and production. Countries can use these results to analyse resource utilisation resulting from their local production, production efficiencies, and environmental impacts caused by interdependencies among countries in agri-food sector (Tramberend et al., 2019). The results aim to assist in achieving national commitments towards conserving the global biophysical cropland limits, necessary to achieve sustainable consumption and production under SDG 12. Agri-food trade policies should take into account the direct (domestic) and indirect (overseas) cropland impacts of domestic agri-food consumption. Bilateral and multilateral trade agreements should consider national environmental limits, and the potential consequences of imports and exports on the environmental limits of agri-food producers. Measures towards reducing the consumption- and production-based impacts on cropland resources are essential to reduce stress on the Land-System Change planetary boundary.

\subsection{Uncertainty, limitations, and future research}

While we selected cropland to represent the global Land-System Change planetary boundary, we acknowledge the limitations with this indicator and the existing debate about the amount of available cropland globally and its reduction with time (Steffen et al., 2015; Usubiaga-Liaño et al., 2019). To incorporate uncertainty in global environmental limits for cropland we included lower, best, and upper estimates based on previous formulations of the cropland boundary (Henry et al., 2018; Nykvist et al., 2013; Springmann et al., 2018; UNCCD, 2017; UNEP, 2014). Our fair-share environmental limits varied over time with population, while we assumed constant biophysical environmental limits of countries based on Eitelberg et al. (2015) "low" potentially available cropland estimated by Eitelberg et al. (2015). However, in reality cropland areas are dynamic with expansion occurring in some areas via deforestation, while in other areas, the amount of arable land is contracting due to factors such as land abandonment and climate change (Doelman et al., 2018).

Exiobase 3.0 MRIO database provided a detailed cropland environmental extension to capture cropland footprints, however, its geographical and temporal coverage is limited (Stadler et al., 2018). Other MRIO databases have a higher geographical resolution (EORA and GTAP databases) but they lack cropland extensions (Andrew and Peters, 2013; Lenzen et al., 2013). Nevertheless, our current geographical and temporal resolution provided sufficient information to downscale the global Land-System Change boundary and calculate country-level utilisation for cropland environmental limit. The framework developed in this study can be used to identify the commodities and products responsible for the direct and indirect environmental impacts. While in-depth commodity-level analysis of cropland flows is outside the scope of this study, further research should focus on exploring the direct and indirect impacts of commodities and their contributions in environmental limit exceedances of other countries. Beyond cropland, further application of this framework can quantify the impacts on freshwater and other environmental resources, and GHG emissions to identify the key commodities responsible for the exceedance across countries on different planetary boundaries. 


\section{Conclusion}

We developed a framework to allocate environmental limits for agri-food consumption and production and contribute towards the operationalisation of the planetary boundary framework in the context of global cropland footprints. Our study enables the assessment of national environmental impacts of consumption and production activities in conjunction to environmental limits for cropland use. This will help countries to effectively monitor their SDG12 progress, analyse their cropland use indicator in line with globally defined targets, selfassess, monitor their domestic and overseas environmental degradation, and optimise the trade of agri-food products. Countries that are exceeding their biophysical environmental limits must revisit their direct/indirect cropland use and negotiate their trade relationships to minimise their cropland impacts. The results can be used as a basis for countries to act as individual entities or together in groups, in order to develop policies that mitigate their global cropland impacts and minimise the risks associated with the exceedance of the Land-System Change planetary boundary.

\section{Acknowledgement}

The study was supported by Deakin University, Australia.

\section{References}

Acquaye, A.A., Wiedmann, T., Feng, K., Crawford, R.H., Barrett, J., Kuylenstierna, J., Duffy, A.P., Koh, S.C., McQueen-Mason, S., 2011. Identification of 'carbon hot-spots' and quantification of GHG intensities in the biodiesel supply chain using hybrid LCA and structural path analysis. Environmental Science \& Technology 45, 2471-2478.

Andrew, R.M., Peters, G.P., 2013. A Multi-Region Input-Output Table Based on the Global Trade Analysis Project Database (Gtap-Mrio). Economic Systems Research 25, 99-121.

Behrens, P., Kiefte-de Jong, J.C., Bosker, T., Rodrigues, J.F.D., de Koning, A., Tukker, A., 2017. Evaluating the environmental impacts of dietary recommendations. Proceedings of the National Academy of Sciences 114, 13412-13417.

Bruckner, M., Fischer, G., Tramberend, S., Giljum, S., 2015. Measuring telecouplings in the global land system: A review and comparative evaluation of land footprint accounting methods. Ecological Economics 114, 11-21.

Chaudhary, A., Krishna, V., 2019. Country-Specific Sustainable Diets Using Optimization Algorithm. Environmental Science \& Technology 53, 7694-7703.

Conijn, J.G., Bindraban, P.S., Schröder, J.J., Jongschaap, R.E.E., 2018. Can our global food system meet food demand within planetary boundaries? Agriculture, Ecosystems \& Environment 251, 244-256.

Croft, S.A., West, C.D., Green, J.M.H., 2018. Capturing the heterogeneity of sub-national production in global trade flows. Journal of Cleaner Production 203, 1106-1118. 
Cuypers, D., Geerken, T., Gorissen, L., Lust, A., Peters, G., Karstensen, J., Prieler, S., Fischer, G., Hizsnyik, E., 2013. Comprehensive Analysis of the Impact of EU Consumption on Deforestation. European Commission.

Dao, H., Peduzzi, P., Friot, D., 2018. National environmental limits and footprints based on the Planetary Boundaries framework: The case of Switzerland. Global Environmental Change $52,49-57$.

Davis, K.F., Rulli, M.C., Seveso, A., D’Odorico, P., 2017. Increased food production and reduced water use through optimized crop distribution. Nature Geoscience 10, 919-924.

Doelman, J.C., Stehfest, E., Tabeau, A., van Meijl, H., Lassaletta, L., Gernaat, D.E.H.J., Hermans, K., Harmsen, M., Daioglou, V., Biemans, H., van der Sluis, S., van Vuuren, D.P., 2018. Exploring SSP land-use dynamics using the IMAGE model: Regional and gridded scenarios of land-use change and land-based climate change mitigation. Global Environmental Change 48, 119-135.

Eitelberg, D.A., van Vliet, J., Verburg, P.H., 2015. A review of global potentially available cropland estimates and their consequences for model-based assessments. Global Change Biology 21, 1236-1248.

Fang, K., Heijungs, R., De Snoo, G.R., 2015a. Understanding the complementary linkages between environmental footprints and planetary boundaries in a footprint-boundary environmental sustainability assessment framework. Ecological Economics 114, 218-226.

Fang, K., Heijungs, R., Duan, Z., de Snoo, G., 2015b. The Environmental Sustainability of Nations: Benchmarking the Carbon, Water and Land Footprints against Allocated Planetary Boundaries. Sustainability 7, 11285-11305.

Godfray, H.C.J., Beddington, J.R., Crute, I.R., Haddad, L., Lawrence, D., Muir, J.F., Pretty, J., Robinson, S., Thomas, S.M., Toulmin, C., 2010. Food security: the challenge of feeding 9 billion people. Science $327,812-818$.

Gopalakrishnan, G., Cristina Negri, M., Snyder, S.W., 2011. A novel framework to classify marginal land for sustainable biomass feedstock production. Journal of environmental quality 40, 1593-1600.

Green, J.M.H., Croft, S.A., Duran, A.P., Balmford, A.P., Burgess, N.D., Fick, S., Gardner, T.A., Godar, J., Suavet, C., Virah-Sawmy, M., Young, L.E., West, C.D., 2019. Linking global drivers of agricultural trade to on-the-ground impacts on biodiversity. Proceedings of the National Academy of Sciences of the United States of America.

Häyhä, T., Lucas, P.L., van Vuuren, D.P., Cornell, S.E., Hoff, H., 2016. From Planetary Boundaries to national fair shares of the global safe operating space - How can the scales be bridged? Global Environmental Change 40, 60-72.

Heck, V., Hoff, H., Wirsenius, S., Meyer, C., Kreft, H., 2018. Land use options for staying within the Planetary Boundaries - Synergies and trade-offs between global and local sustainability goals. Global Environmental Change 49, 73-84. 
Henry, R.C., Engstrom, K., Olin, S., Alexander, P., Arneth, A., Rounsevell, M.D.A., 2018. Food supply and bioenergy production within the global cropland planetary boundary. PLoS One 13, e0194695.

Hoekstra, A.Y., Wiedmann, T.O., 2014. Humanity's unsustainable environmental footprint. Science 344, 1114-1117.

Hoff, H., Nykvist, B., Carson, M., 2014. "Living well, within the limits of our planet"? Measuring Europe's growing external footprint. Stockholm Environment Institute, 20142015.

Kastner, T., Erb, K.-H., Haberl, H., 2014a. Rapid growth in agricultural trade: effects on global area efficiency and the role of management. Environmental Research Letters 9, 034015 .

Kastner, T., Schaffartzik, A., Eisenmenger, N., Erb, K.-H., Haberl, H., Krausmann, F., 2014b. Cropland area embodied in international trade: Contradictory results from different approaches. Ecological Economics 104, 140-144.

Kissinger, M., Rees, W.E., 2010. An interregional ecological approach for modelling sustainability in a globalizing world-Reviewing existing approaches and emerging directions. Ecological Modelling 221, 2615-2623.

Lambin, E.F., Gibbs, H.K., Ferreira, L., Grau, R., Mayaux, P., Meyfroidt, P., Morton, D.C., Rudel, T.K., Gasparri, I., Munger, J., 2013. Estimating the world's potentially available cropland using a bottom-up approach. Global Environmental Change 23, 892-901.

Lenzen, M., Moran, D., Kanemoto, K., Geschke, A., 2013. Building Eora: A Global MultiRegion Input-Output Database at High Country and Sector Resolution. Economic Systems Research 25, 20-49.

Lenzen, M., Murray, J., Sack, F., Wiedmann, T., 2007. Shared producer and consumer responsibility - Theory and practice. Ecological Economics 61, 27-42.

Leontief, W., 1970. Environmental Repercussions and the Economic Structure: An InputOutput Approach. The Review of Economics and Statistics 52, 262-271.

Li, M., Wiedmann, T., Hadjikakou, M., 2019. Towards meaningful consumption-based planetary boundary indicators: The phosphorus exceedance footprint. Global Environmental Change 54, 227-238.

Liu, J., Mooney, H., Hull, V., Davis, S.J., Gaskell, J., Hertel, T., Lubchenco, J., Seto, K.C., Gleick, P., Kremen, C., Li, S., 2015. Sustainability. Systems integration for global sustainability. Science 347, 1258832.

Meyer, K., Newman, P., 2018. The Planetary Accounting Framework: a novel, quota-based approach to understanding the impacts of any scale of human activity in the context of the Planetary Boundaries. Sustainable Earth 1.

Newbold, T., Hudson, L.N., Arnell, A.P., Contu, S., De Palma, A., Ferrier, S., Hill, S.L., Hoskins, A.J., Lysenko, I., Phillips, H.R., 2016. Has land use pushed terrestrial biodiversity beyond the planetary boundary? A global assessment. Science 353, 288-291. 
Nykvist, B., Persson, A., Moberg, F., Persson, L.M., Cornell, S.E., Rockström, J., 2013. National Environmental Performance on Planetary Boundaries: A study for the Swedish Environmental Protection Agency.

O’Neill, D.W., Fanning, A.L., Lamb, W.F., Steinberger, J.K., 2018. A good life for all within planetary boundaries. Nature Sustainability 1, 88-95.

Osei-Owusu, A.K., Kastner, T., de Ruiter, H., Thomsen, M., Caro, D., 2019. The global cropland footprint of Denmark's food supply 2000-2013. Global Environmental Change 58.

Peters, G.P., 2008. From production-based to consumption-based national emission inventories. Ecological Economics 65, 13-23.

Ramankutty, N., Mehrabi, Z., Waha, K., Jarvis, L., Kremen, C., Herrero, M., Rieseberg, L.H., 2018. Trends in Global Agricultural Land Use: Implications for Environmental Health and Food Security. Annual Review of Plant Biology 69, 789-815.

Rockström, J., Steffen, W., Noone, K., Persson, Å., Chapin III, F.S., Lambin, E.F., Lenton, T.M., Scheffer, M., Folke, C., Schellnhuber, H.J.J.n., 2009. A safe operating space for humanity. Nature 461, 472.

Rodrigues, J.F.D., Moran, D., Wood, R., Behrens, P., 2018. Uncertainty of ConsumptionBased Carbon Accounts. Environmental Science \& Technology 52, 7577-7586.

Schneider, F., Buehn, A., Montenegro, C.E. 2011. Shadow economies all over the world: New estimates for 162 countries from 1999 to 2007.

Simas, M., Pauliuk, S., Wood, R., Hertwich, E.G., Stadler, K., 2017. Correlation between production and consumption-based environmental indicators. Ecological Indicators 76, 317 323.

Springmann, M., Clark, M., Mason-D’Croz, D., Wiebe, K., Bodirsky, B.L., Lassaletta, L., de Vries, W., Vermeulen, S.J., Herrero, M., Carlson, K.M., 2018. Options for keeping the food system within environmental limits. Nature 562, 519.

Stadler, K., Wood, R., Bulavskaya, T., Södersten, C.-J., Simas, M., Schmidt, S., Usubiaga, A., Acosta-Fernández, J., Kuenen, J., Bruckner, M., Giljum, S., Lutter, S., Merciai, S., Schmidt, J.H., Theurl, M.C., Plutzar, C., Kastner, T., Eisenmenger, N., Erb, K.-H., de Koning, A., Tukker, A., 2018. EXIOBASE 3: Developing a Time Series of Detailed Environmentally Extended Multi-Regional Input-Output Tables. Journal of Industrial Ecology.

Steffen, W., Richardson, K., Rockstrom, J., Cornell, S.E., Fetzer, I., Bennett, E.M., Biggs, R., Carpenter, S.R., de Vries, W., de Wit, C.A., Folke, C., Gerten, D., Heinke, J., Mace, G.M., Persson, L.M., Ramanathan, V., Reyers, B., Sorlin, S., 2015. Sustainability. Planetary boundaries: guiding human development on a changing planet. Science 347, 1259855.

Steffen, W., Rockström, J., Richardson, K., Lenton, T.M., Folke, C., Liverman, D., Summerhayes, C.P., Barnosky, A.D., Cornell, S.E., Crucifix, M., Donges, J.F., Fetzer, I., Lade, S.J., Scheffer, M., Winkelmann, R., Schellnhuber, H.J., 2018. Trajectories of the Earth System in the Anthropocene. Proceedings of the National Academy of Sciences 115, 82528259. 
Suh, S., Huppes, G., 2005. Methods for Life Cycle Inventory of a product. Journal of Cleaner Production 13, 687-697.

Sun, Z., Scherer, L., Tukker, A., Behrens, P., 2019. Linking global crop and livestock consumption to local production hotspots. Global Food Security.

Tramberend, S., Fischer, G., Bruckner, M., van Velthuizen, H., 2019. Our Common Cropland: Quantifying Global Agricultural Land Use from a Consumption Perspective. Ecological Economics 157, 332-341.

Tukker, A., Bulavskaya, T., Giljum, S., de Koning, A., Lutter, S., Simas, M., Stadler, K., Wood, R., 2016. Environmental and resource footprints in a global context: Europe's structural deficit in resource endowments. Global Environmental Change 40, 171-181.

Turner, K., Lenzen, M., Wiedmann, T., Barrett, J., 2007. Examining the global environmental impact of regional consumption activities - Part 1: A technical note on combining inputoutput and ecological footprint analysis. Ecological Economics 62, 37-44.

UN, 2015. Transforming our World: The 2030 Agenda for Sustainable Development.

UN, 2017. World Population Prospects: The 2017 Revision. Department of Economic and Social Affairs, Population Division.

UNCCD, 2017. The Global Land Outlook, first edition, Bonn, Germany.

UNEP, 2014. UNEP 2014 Annual Report. United Nations.

Usubiaga-Liaño, A., Mace, G.M., Ekins, P., 2019. Limits to agricultural land for retaining acceptable levels of local biodiversity. Nature Sustainability 2, 491-498.

Van Vuuren, D.P., Faber, A., 2009. Growing within limits. A report to the Global Assembly 2009 of the Club of Rome. Netherlands Environmental Assessment Agency PBL.

Weinzettel, J., Hertwich, E.G., Peters, G.P., Steen-Olsen, K., Galli, A., 2013. Affluence drives the global displacement of land use. Global Environmental Change 23, 433-438.

West, P.C., Narisma, G.T., Barford, C.C., Kucharik, C.J., Foley, J.A., 2010. An alternative approach for quantifying climate regulation by ecosystems. Frontiers in Ecology and the Environment 9, 126-133.

Wiedmann, T., Lenzen, M., 2018. Environmental and social footprints of international trade. Nature Geoscience 11, 314-321.

Wiedmann, T., Wilting, H.C., Lenzen, M., Lutter, S., Palm, V., 2011a. Quo Vadis MRIO? Methodological, data and institutional requirements for multi-region input-output analysis. Ecological Economics 70, 1937-1945.

Wiedmann, T.O., Suh, S., Feng, K., Lenzen, M., Acquaye, A., Scott, K., Barrett, J.R., 2011 b. Application of hybrid life cycle approaches to emerging energy technologies--the case of wind power in the UK. Environmental Science \& Technology 45, 5900-5907. 
Willett, W., Rockström, J., Loken, B., Springmann, M., Lang, T., Vermeulen, S., Garnett, T., Tilman, D., DeClerck, F., Wood, A., Jonell, M., Clark, M., Gordon, L.J., Fanzo, J., Hawkes, C., Zurayk, R., Rivera, J.A., De Vries, W., Majele Sibanda, L., Afshin, A., Chaudhary, A., Herrero, M., Agustina, R., Branca, F., Lartey, A., Fan, S., Crona, B., Fox, E., Bignet, V., Troell, M., Lindahl, T., Singh, S., Cornell, S.E., Srinath Reddy, K., Narain, S., Nishtar, S., Murray, C.J.L., 2019. Food in the Anthropocene: the EAT-Lancet Commission on healthy diets from sustainable food systems. The Lancet 393, 447-492.

Wood, R., Stadler, K., Simas, M., Bulavskaya, T., Giljum, S., Lutter, S., Tukker, A., 2018. Growth in Environmental Footprints and Environmental Impacts Embodied in Trade:

Resource Efficiency Indicators from EXIOBASE3. Journal of Industrial Ecology 22, 553 564.

Yu, Y., Feng, K., Hubacek, K., 2013. Tele-connecting local consumption to global land use. Global Environmental Change 23, 1178-1186.

Yu, Y., Feng, K., Hubacek, K., Sun, L., 2016. Global Implications of China's Future Food Consumption. Journal of Industrial Ecology 20, 593-602.

Zhao, F.-J., Ma, Y., Zhu, Y.-G., Tang, Z., McGrath, S.P., 2014. Soil contamination in China: current status and mitigation strategies. Environmental Science \& Technology 49, 750-759. 


\title{
Patterns and trends in national-level consumption and production-based utilisation of the land-system change planetary boundary
}

\author{
M. Abdullah Shaikh ${ }^{a},{ }^{*}$, Michalis Hadjikakou ${ }^{a}$, Brett A. Bryan ${ }^{a}$ \\ ${ }^{a}$ Centre for Integrative Ecology, School of Life \& Environmental Sciences, Deakin University, Melbourne \\ Burwood Campus, Burwood, VIC, 3125, Australia
}

*Corresponding author.E-mail address: mashai@deakin.edu.au

\section{Supporting Data}

https://bit.ly/3evqnIU

\section{Supporting Information}

\section{Appendix 1}

\subsection{MRIO Approach}

Environmentally extended multiregional input-output (EE-MRIO) analysis is the state-of-theart method for calculating country-level, consumption and production-based footprints (Wiedmann and Lenzen, 2018). It enables quantification of the socio-economicenvironmental impacts associated with the global trade of goods and services. EEMRIO analysis, in conjunction with Leontief's demand-pull model, enables the calculation of the direct (domestic) and indirect (international/virtual) displacement of cropland impacts embodied in global trade (Acquaye et al., 2011; Hoekstra and Wiedmann, 2014; Liu et al., 2015a; Suh and Huppes, 2005; Wiedmann et al., 2011b)

MRIO covers the entire supply chain transactions, from initial production to the intermediate processes till the final consumption, to calculate the impacts of environmental indicators like GHG emissions, water footprints, land footprints, biodiversity and several other socio-economic parameters (Arto et al. 2012; Bruckner et al. 2015; Feng et al. 2011; Frischknecht et al. 2014; Kitzes 2013; Lan et al. 2016; Lenzen et al. 2012; Simas et al. 2017; Weinzettel et al. 2013; Wiedmann 2009; Wiedmann et al. 2011; Wiedmann et al. 2015; Wood et al. 2018a). We used the EXIOBASE 3.0 MRIO database to calculate national cropland footprints for consumption and production (Stadler et al. 2018). EXIOBASE aggregates the global supply chain into 44 countries and 5 world regions (Table A1.1). 
Table A1.1 EXIOBASE MRIO country resolution

\begin{tabular}{llllll}
\hline & 27 EU Countries & \multicolumn{2}{c}{ 17 World regions } & RoW regions \\
\hline Austria & Finland & Latvia & United Kingdom & Russia & \\
Belgium & France & Malta & United States & Australia & RoW Asia Pacific \\
Bulgaria & Greece & Romania & Japan & Switzerland & RoW America \\
Cyprus & Croatia & Sweden & China & Turkey & RoW Europe \\
Czech Republic & Hungary & Netherlands & Canada & Taiwan & RoW Africa \\
Germany & Ireland & Poland & South Korea & Norway & RoW Middle East \\
Denmark & Italy & Portugal & Brazil & Indonesia & Total Countries: 44 \\
Estonia & Lithuania & Slovenia & India & South Africa & RoW regions: 05 \\
Spain & Luxemburg & Slovak Republic & Mexico & & \\
\hline
\end{tabular}

The building block of MRIO analysis are the multi-regional input-output (IO) tables containing country-to-country economic trade transactions (also called as intermediate demand), value added transactions required as input for the economic activities and final demand from countries. These tables are financially balanced accounts of supply chain interactions of the global economy. Table A1.2 provides an example of the type of information describing the monetary transactions between countries.

Table A1.2 Global supply chain transactions.

\begin{tabular}{|c|c|c|c|c|}
\hline & Country $X$ & Country $Y$ & Country Z & \\
\hline Country $X$ & Domestic transactions in $\mathrm{X}$ & Trade from $X$ to $Y$ & Trade from $X$ to $Z$ & Final demand in $\mathrm{X}$ \\
\hline Country $Y$ & Trade from $Y$ to $X$ & Domestic transactions in $Y$ & Trade from $Y$ to $Z$ & Final demand in $Y$ \\
\hline \multirow[t]{2}{*}{ Country Z } & Trade from $\mathrm{Z}$ to $\mathrm{X}$ & Trade from $Z$ to $Y$ & Domestic transactions in $\mathrm{Z}$ & Final demand in $\mathrm{Z}$ \\
\hline & Value added in X & Value added in $Y$ & Value added in Z & \\
\hline
\end{tabular}

The sectoral resolution can be increased to study industry-level trade transactions. For example (Table A1.3), $Y_{\mathrm{Mf}, \mathrm{Hh}}^{\mathrm{X}}$ represents the final demand of manufactured products by households in country X. $T_{\mathrm{Ag}, \mathrm{Mf}}^{\mathrm{X}, \mathrm{Z}}$ represents the international trade of agriculture commodities produced in country X received by manufacturing sectors in country $Z$ (Lenzen et al. 2013).

Table A1.3 Sector resolution in MRIO table.

\begin{tabular}{|c|c|c|c|c|c|}
\hline & $\mathrm{Ag} \mathrm{Z}$ & Mf Z & Sv Z & $\mathrm{Hh}$ & Cap \\
\hline Agriculture(Ag) $X$ & $T_{\mathrm{Ag}, \mathrm{Ag}}^{\mathrm{X}, \mathrm{Z}}$ & $T_{\mathrm{Ag}, \mathrm{Mf}}^{\mathrm{X}, \mathrm{Z}}$ & $T_{\mathrm{Ag}, \mathrm{Sv}}^{\mathrm{X}, \mathrm{Z}}$ & $Y_{\mathrm{Ag}, \mathrm{Hh}}^{\mathrm{X}}$ & $Y_{\mathrm{Ag}, \mathrm{Cap}}^{\mathrm{X}} \cdots$ \\
\hline Manufacturing(Mf) $X$ & $T_{\mathrm{Mf}, \mathrm{Ag}}^{\mathrm{X}, \mathrm{Z}}$ & $T_{\mathrm{Mf}, \mathrm{Mf}}^{\mathrm{X}, \mathrm{Z}}$ & $T_{\mathrm{Mf}, \mathrm{Sv}}^{\mathrm{X}, \mathrm{Z}}$ & $Y_{\mathrm{Mf}, \mathrm{Hh}}^{\mathrm{X}}$ & $Y_{\mathrm{Mf}, \mathrm{Cap}}^{\mathrm{X}} \cdots$ \\
\hline Services(Sv) X & $T_{\mathrm{Sv}, \mathrm{Ag}}^{\mathrm{X}, \mathrm{Z}}$ & $T_{\mathrm{Sv}, \mathrm{Mf}}^{\mathrm{X}, \mathrm{Z}}$ & $T_{\mathrm{Sv}, \mathrm{Sv}}^{\mathrm{X}, \mathrm{Z}}$ & $Y_{\mathrm{Sv}, \mathrm{Hh}}^{\mathrm{X}}$ & $Y_{\mathrm{Sv}, \mathrm{Cap}}^{\mathrm{X}} \cdots$ \\
\hline Households(Hh) & $v_{\mathrm{Hh}, \mathrm{Ag}}^{\mathrm{Z}}$ & $v_{\mathrm{Hh}, \mathrm{Mf}}^{\mathrm{Z}}$ & $v_{\mathrm{Hh}, \mathrm{Mf}}^{\mathrm{Z}}$ & & \\
\hline Capital(Cap) & $v_{\text {Cap,Ag }}^{\mathrm{Z}}$ & $v_{\text {Cap,Mf }}^{\mathrm{Z}}$ & $v_{\text {Cap,Sv }}^{\mathrm{Z}}$ & & \\
\hline
\end{tabular}




\section{Appendix 2}

\subsection{Classification of countries and regions}

Table A2.1: Classification of countries (and regions) in Figure 6

\begin{tabular}{|l|l|l|l|}
\hline Africa (Others) & South Africa & RoW Africa & \\
\hline America (Others) & Canada & RoW America & \\
\hline \multirow{4}{*}{ Asia (Others) } & Japan & Russian Federation & Taiwan \\
\cline { 2 - 4 } & South Korea & RoW Middle East & RoW Asia \\
\hline \multirow{5}{*}{ Europe (Others) } & Austria & Finland & Latvia \\
\cline { 2 - 4 } & Belgium & France & Malta \\
\cline { 2 - 4 } & Bulgaria & Greece & Romania \\
\cline { 2 - 4 } & Cyprus & Croatia & Sweden \\
\cline { 2 - 4 } & Czech Republic & Hungary & Netherlands \\
\cline { 2 - 4 } & Germany & Ireland & Poland \\
\cline { 2 - 4 } & Denmark & Italy & Sortugal \\
\cline { 2 - 4 } & Estonia & Lithuania & Slovak Republic \\
\cline { 2 - 4 } & Spain & Luxembourg & United Kingdom \\
\cline { 2 - 4 } & Switzerland & Norway & \\
\cline { 2 - 4 } & RoW Europe & & \\
\hline
\end{tabular}




\section{Appendix 3}

Cropland PB vs Consumption-based Footprin
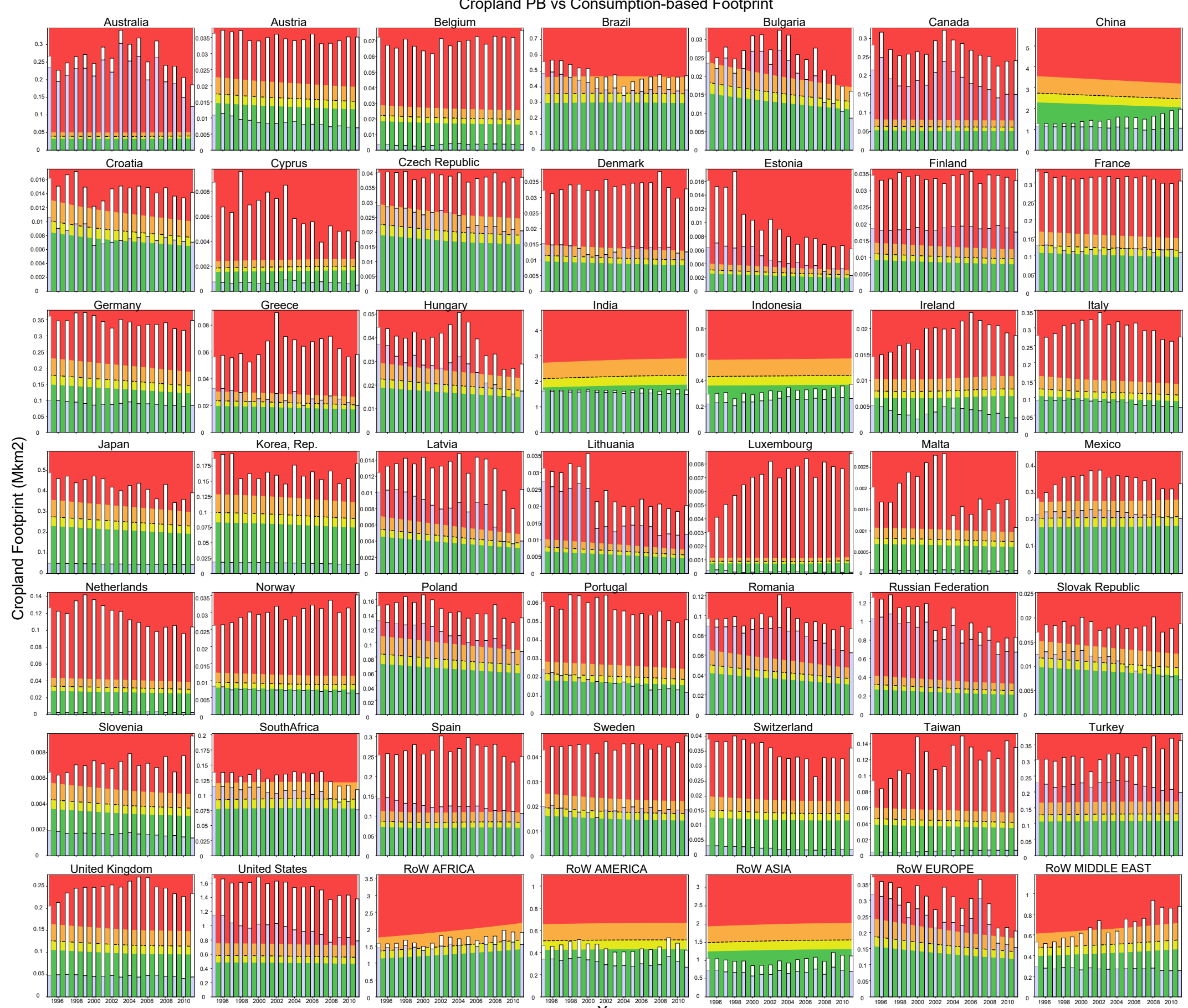

colours show the footprints against their fair-share environmental limit. Background cropland footprint by countries over time. Note that the scale of y-axis is unique for each country due to the difference in environmental limits and cropland footprints. 


\section{Appendix 4}

\subsection{References}

Arto, I., Andreoni, V., Rueda-Cantuche, J., 2012. Water use, water footprint and virtual water trade: a time series analysis of worldwide water demand, The 20th International Input-Output Conference. Lager C.(ed.). International Input-Output Association, Bratislava, Slovakia.

Bruckner, M., Fischer, G., Tramberend, S., Giljum, S., 2015. Measuring telecouplings in the global land system: A review and comparative evaluation of land footprint accounting methods. Ecological Economics 114, 11-21.

Feng, K., Chapagain, A., Suh, S., Pfister, S., Hubacek, K., 2011. Comparison of Bottom-up and Topdown Approaches to Calculating the Water Footprints of Nations. Economic Systems Research 23, 371-385.

Frischknecht, R., Knöpfel, S.B., 2014. Ecological scarcity 2013 - new features and its application in industry and administration - 54th LCA forum, Ittigen/Berne, Switzerland, December 5, 2013. The International Journal of Life Cycle Assessment 19, 1361-1366.

Kitzes, J., 2013. An introduction to environmentally-extended input-output analysis. Resources 2, 489-503.

Lan, J., Malik, A., Lenzen, M., McBain, D., Kanemoto, K., 2016. A structural decomposition analysis of global energy footprints. Applied Energy 163, 436-451.

Lenzen, M., Moran, D., Bhaduri, A., Kanemoto, K., Bekchanov, M., Geschke, A., Foran, B., 2013. International trade of scarce water. Ecological Economics 94, 78-85.

Lenzen, M., Moran, D., Kanemoto, K., Foran, B., Lobefaro, L., Geschke, A., 2012. International trade drives biodiversity threats in developing nations. Nature 486, 109-112.

Simas, M., Pauliuk, S., Wood, R., Hertwich, E.G., Stadler, K., 2017. Correlation between production and consumption-based environmental indicators: The link to affluence and the effect on ranking environmental performance of countries. Ecological Indicators 76, 317-323.

Stadler, K., Wood, R., Bulavskaya, T., Södersten, C.-J., Simas, M., Schmidt, S., Usubiaga, A., Acosta-Fernández, J., Kuenen, J., Bruckner, M., Giljum, S., Lutter, S., Merciai, S., Schmidt, J.H., Theurl, M.C., Plutzar, C., Kastner, T., Eisenmenger, N., Erb, K.-H., de Koning, A., Tukker, A., 2018. EXIOBASE 3: Developing a Time Series of Detailed Environmentally Extended Multi-Regional Input-Output Tables. Journal of Industrial Ecology.

Weinzettel, J., Hertwich, E.G., Peters, G.P., Steen-Olsen, K., Galli, A., 2013. Affluence drives the global displacement of land use. Global Environmental Change 23, 433-438.

Wiedmann, T., 2009. A first empirical comparison of energy Footprints embodied in trade - MRIO versus PLUM. Ecological Economics 68, 1975-1990.

Wiedmann, T., Wilting, H.C., Lenzen, M., Lutter, S., Palm, V., 2011. Quo Vadis MRIO?

Methodological, data and institutional requirements for multi-region input-output analysis. Ecological Economics 70, 1937-1945.

Wiedmann, T.O., Schandl, H., Lenzen, M., Moran, D., Suh, S., West, J., Kanemoto, K., 2015. The material footprint of nations. Proceedings of the National Academy of Sciences of the United States of America 112, 6271-6276.

Wood, R., Stadler, K., Simas, M., Bulavskaya, T., Giljum, S., Lutter, S., Tukker, A., 2018. Growth in Environmental Footprints and Environmental Impacts Embodied in Trade: Resource Efficiency Indicators from EXIOBASE3. Journal of Industrial Ecology 22, 553-564. 